Volume 6 Issue 1, March 2021:pp. 41-55 Copyright @ LamLaj. Faculty of Law, Lambung Mangkurat University, Banjarmasin, South Kalimantan, Indonesia. ISSN: 2502-3136 | e-ISSN: 2502-3128.

Open Access at: http://lamlaj.ulm.ac.id/web/

\title{
PROGRESSIVISM OF JUDGES IN DECIDING APPLICATIONS FOR MARRIAGE DISPENSATION
}

\author{
Josua Navirio Pardede ${ }^{1}$, Wigati Taberi Asih ${ }^{2}$, Thogu Ahmad Siregar ${ }^{3}$ \\ ${ }^{1}$ Faculty of Law, Gadjah Mada University
}

Jl. Sosio Yustisia No. 1, Bulaksumur, Daerah Istimewa Yogyakarta, Indonesia 55281

Email : josuanavirio1996@mail.ugm.ac.id

${ }^{2}$ Faculty of Law, Gadjah Mada University

Jl. Sosio Yustisia No. 1, Bulaksumur, Daerah Istimewa Yogyakarta, Indonesia 55281

Email :wigatitaberi98@mail.ugm.ac.id

${ }^{3}$ Faculty of Law, Gadjah Mada University

Jl. Sosio Yustisia No. 1, Bulaksumur, Daerah Istimewa Yogyakarta, Indonesia 55281

Email :thogu.a.s@mail.ugm.ac.id

Submitted : 16/12/2020 Reviewed:21/02/2021 Accepted:26/02/2021

\begin{abstract}
Regulation on the age limit for a marriage through Act No. 16 of 2019 is based on the spirit of anti-discrimination and protection of children's rights from the adverse effects of child marriage. However, the efforts to complicate and prevent child marriage has yet to have a significant impact on reducing the rate of child marriage in Indonesia. This condition is occurred by the high level of applications for marriage dispensation that are granted by the court. Hence, the construction of the judge's reasoning in observe the relationship between the substance of the law and the reasons for proposing marriage dispensation is one of the most vital and influential elements. The positivism-legism legal reasoning used in understanding of Act No.16 of 2019 is considered to be the cause of the malfunction of the regulation in protecting and guaranteeing children's human rights. By using doctrinal legal research methods, this research produces a conceptual analysis in the form of a meta-juridical critique on positivist legal reasoning which tends to lead to the legism when trying to understand the objectives of Act No. 16 of 2019 and proposes a progressive legal notion as an ideal reasoning framework in producing decisions on applications for dispensation of marriage that have a perspective on the protection and guarantee of children's rights.
\end{abstract}

Keywords: marriage dispensation; legal progressivism

DOI : 10.32801/lamlaj.v6i1.208 


\section{INTRODUCTION}

In the course of human civilization, marriage has become one of the essential concepts that has always been developing, criticizing and reconstructing in accordance with the dynamics that occur in society. Has a very strong influence in various other areas of life such as politics, economy and culture. Marriage has existed since it was first recorded in historical records, which is around $2000 \mathrm{BC}(\mathrm{BC})$ in the Babylonian region (now Iraq). In the following centuries the concept of marriage has continued to develop for approximately 4000 years until it reaches the 21 st century, where almost all systems of society in the world understand that marriage does not only have biological consequences but also various other consequences such as economic and juridi$\mathrm{cal}^{1}$, including in society. Indonesia.

In general, the demographic construction of the population as a vital component in the social system of Indonesian society is classified into the young pyramid group. ${ }^{2}$ Age projection data in the youth pyramid in Indonesia shows the high number of one of the vulnerable age groups, children, with a number reaching 93,106,200. ${ }^{3}$ In addition, the high number of young people raises a num-

${ }^{1}$ Stephanie Coontz, Marriage, a History: From Obedience to Intimacy or How Love Conquered Marriage. (New York: Viking Books, 2006), 15-19.

2 M. Baiquni, "Revolusi Industri, Ledakan Penduduk dan Masalah Lingkungan", Jurnal Sains dan Teknologi Lingkungan 1, no. 1 (2009): 44-46, https:// journal.uii.ac.id/JSTL/article/view/3568/3158. The term "Young Pyramid" here is a sub-group in the population pyramid or pattern of describing the population of the age distribution, where the young pyramid is a pattern that describes the high growth rate of young people supported by high birth rates.

3 "Proyeksi Penduduk Indonesia (Indonesia Population Projection) 2010-2035," Badan Perencanaan Pembangunan Nasional Badan Pusat Statistik, last modified 2013, accessed November 20, 2020, ber of related issues, including the high rate of marriage.

The high rate of marriage is not free from the problems that occur therein. One of them is the phenomenon of child marriage. Data from UNICEF (United Nation Children's Fund), shows that in Southeast Asia 30\% of women are married under the age of $18 .{ }^{4}$ In Indonesia, the percentage of women who are married under the age of 18 is $18 \%$ and under the age of 15 is $2 \%$, while the percentage of men who are married under the age of 18 is $5 \% .^{5}$ One of the arrangements related to this issue is contained in Article 7 paragraph (1) of Law no. 16 of 2019 concerning Amendments to Law No.1 of 1974 concerning Marriage (Law No.16 / 2019) which stipulates that the minimum age of marriage is 19 years for men and women. Then in Article 7 paragraph (2) Law No.16 / 2019 it is also explained that if a deviation is to be made to this, it must be based on very urgent reasons and be accompanied by sufficient evidence to further apply for dispensation of marriage to the court. So if you look at the existence of these provisions, Law No.16 / 2019 actually does not prohibit or close the possibility of child marriage but instead seeks to limit child marriage, which in Indonesia is still quite high.

This then raises a number of questions, in particular related to how legal considerations and methods of reasoning are used by the judge as the only entity authorized to decide on the marriage dispensation application, and how legal progressivism can be used in

https://www.bappenas.go.id/files/5413/9148/4109/ Proyeksi_Penduduk_Indonesia_2010-2035.pdf.

4 “Child Marriage," United Nation Children's Fund, last modified 2020, accessed November 20, 2020, https://data.unicef.org/topic/child-protection/childmarriage/.

${ }^{5}$ Ibid. 
assessing an application for dispensation of marriage.

So as a whole, this paper aims to analyze the pattern of legal reasoning used to produce a decision on application for marriage dispensation that has a perspective on substantive justice and protection for children.

\section{METHOD}

In essence, all research must have a line of thought framework which is also called the research method, including legal research, where in this legal research the method used is the doctrinal legal research method.

Doctrinal legal research is research on law that is conceptualized and developed on the basis of the doctrine held by the drafter or developer. The doctrinal method is used as part of a concept that has a moral and philosophical pattern. Sources of information in this paper are obtained using the method of library research, the search for data, information and knowledge contained in the literature. ${ }^{6}$ In the research process, this paper will focus on studying the legal reasoning process used by judges in deciding applications for dispensation of marriage and seeing the relevance of using legal progressivism in understanding the concept of dispensation of marriage contained in Law No. 16/2019.

\section{ANALYSIS AND DISCUSSION}

\section{The Impact of Marriage Dispensation on} Child Marriage in Indonesia

Etymologically, dispensation can be defined as an exception to a general rule for a

\footnotetext{
6 Soetandyo Wignjosoebroto, Hukum: Paradigma, Metode dan Dinamika Masalahnya, (Jakarta: Lembaga Studi dan Advokasi Masyarakat (ELSAM) dan Perkumpulan untuk Pembaruan Hukum Berbasis Masyarakat dan Ekologi (HUMA), 2002), 141-147.
}

specific condition, it can also be interpreted as an exemption from an obligation / obligation or prohibition. So in general it can be understood that this dispensation of marriage is a rule that applies specifically because of certain conditions that prevent a person from marrying according to a predetermined age limit. $^{7}$

Dispensation of marriage as the main idea contained in Article 7 paragraph (2) and (3) Law no. 16/2019 is an application filed by the parents of the male and / or female parents to the local court and is accompanied by an effort to hear the opinions of the two prospective brides in the process specifically for parties who do not meet the minimum age limit of marriage.

In the Constitutional Court Decision No. 22 / PUU-XV / 2017, stated that the difference in the minimum age for marriage is a discriminatory policy because it violates the fulfillment of the basic rights of Indonesian citizens. So that the equalization of the age of children, both boys and girls, then acts as an object that hinders or makes it difficult for underage child marriages to take place. However, post the enactment of Law no. 16/2019, the teleological aspects (ideals) of the regulation do not appear to have been effectively realized.

Changes in norms in Law No.1 / 1974 with Law no. 16/2019 has reached the age limit for marriage by increasing the minimum age of marriage for women. In this case, the minimum age of marriage for women is equal to the minimum age of marriage for men,

\footnotetext{
Mughniatul Ilma, "Regulasi Dispensasi Dalam Penguatan Aturan Batas Usia Kawin Bagi Anak Pasca Lahirnya UU No. 16 Tahun 2019," Al-Manhaj: Jurnal Hukum dan Pranata Sosial Islam 2, no. 2 (2020): 144, https://ejournal.insuriponorogo.ac.id/index.php/ almanhaj/article/view/478.
} 
which is 19 (nineteen) years. The age limit is considered to be mature in body and soul to be able to carry out a marriage in order to realize the goal of marriage properly without ending in divorce and obtaining healthy and quality offspring. It is also hoped that increasing the age limit for women to marry will result in lower birth rates and reduce the risk of maternal and child mortality. Apart from that, children's rights can also be fulfilled so as to optimize children's growth and development, including mentoring parents and giving children the highest possible access to education. ${ }^{8}$

If you look at the conditions in the field, data collected from the Center for Research and Advocacy for the Protection and Quality of Life of Children, University of Indonesia (PUSKAPA-UI), the province with the highest prevalence rate of child marriage in Indonesia, namely South Sulawesi, West Nusa Tenggara, North Maluku, Sulawesi West, as well as almost all provinces in the islands of Sulawesi and Kalimantan, show a higher rate of child marriage than the national rate of child marriage and still have not shown a significant decrease in the rate of child marriage. ${ }^{9}$

For example, as in the province of South

\footnotetext{
${ }^{8}$ Syeh Sarip Hidayatullah and Nurul Huda, "Praktek Hukum Acara Dispensasi Kawin," Asas: The Scientific Journal of Politics, Law, Syari'ah Economic Law and Islamic Culture 12, no. 1 (2020): 167, http://ejournal. radenintan.ac.id/index.php/asas/article/view/7133.

9 "Pencegahan Perkawinan Anak: Percepatan yang Tidak Bisa Ditunda," Puskapa - Center on Child Protection and Wellbeing at Universitas Indonesia, last modified 2020, accessed November 24, 2020, https://www.unicef.org/indonesia/media/2851/ file/Child-Marriage-Report-2020.pdf. The data is processed from other sources, namely the Central Bureau on Statistics (BPS), the Indonesian Ministry of National Development Planning (Bappenas), UNICEF, and the Center for Studies and the Center on Child Protection \& Wellbeing (PUSKAPA).
}

Sulawesi and West Nusa Tenggara, with a prevalence rate of female child marriages which amounted to $14.10 \%$ and ${ }^{10} 15.48 \%$, the application for dispensation to marry in the Religious Maros increase of 203 cases from January to October 2020. ${ }^{11}$ While the percentage of petition Marriage dispensation at the Lombok Religious Court increased by $300 \%$ with 116 applications as of September 2020 compared to only 33 applications in $2019 .{ }^{12}$

Then in Central Java Province, the percentage of girls who are married under age reaches $11.04 \%{ }^{13}$. Then, compiled from the Office for Women's Empowerment and Child Protection (DP3A) in Central Java, child marriage in Central Java increased from before the issuance of Law no. 16/2019, which are 2049 cases (2018-2019), up to 8,338 cases (2019-2020) or there was an almost fourfold increase ${ }^{14}$, while in the capital of Central Java, Semarang, there were 176 couples who applied for dispensation of marriage in Octo-

\footnotetext{
${ }^{10}$ Ibid., 63-64.
}

${ }^{11}$ Andi Muhammad Ikhsan WR, "Hingga Oktober 2020, Permohonan Dispensasi Nikah Di Pengadilan Agama Maros Capai 203 Kasus," TribunMaros, last modified 2020, accessed November 24, 2020, https://makassar. tribunnews.com/2020/11/04/hingga-oktober-2020permohonan-dispensasi-nikah-di-pengadilan-agamamaros-capai-203-kasus.

12 "Permohonan Dispensasi kawin Anak di Loteng Meningkat 300 Persen," RadarLombok, last modified 2020, accessed November, 24, 2020, https://radarlombok.co.id/permohonan-dispensasiperkawinan-meningkat-300-persen.html.

13 "Pencegahan Perkawinan Anak: Percepatan yang Tidak Bisa Ditunda.”

14 “Angka Pernikahan Anak di Jateng Naik Jadi 8.338 Kasus," Kompas, last modified 2020, accessed December, 18, 2020, https://regional.kompas.com/ $\mathrm{read} / 2020 / 11 / 21 / 17464361 /$ angka-pernikahan-anakdi-jateng-naik-jadi-8338-kasus?page=all. 
ber 2020 alone. $^{15}$

These conditions then show that the impact desired by the legislators through the change in the minimum age limit is still not effective because it is still easy for the courts to provide access to the public through this legal loophole which has an impact on the establishment of child marriages through applications for dispensation of marriage as regulated in Article 7. paragraph (2) of this Law 16/2019.

\section{Judges' Considerations in Granting Mar- riage Dispensation}

At the examination of a case, the judge is tasked with constituent (constituent), qualify (qualify) and then constituent (constitute). Constituting means that the judge must judge whether the events or facts brought up by the parties actually happened. This can only be done through evidence. Proving it means considering logically the truth of a fact or event based on valid evidence and according to the applicable law of evidence. ${ }^{16}$

If you look at the regulations on applications for dispensation of marriage as stipulated in Article 7 paragraph (2), which says:

"If there is a deviation from the age requirement, the parents of the male and / or the parents of the female party can request dispensation to the Court with

\footnotetext{
${ }^{15}$ Baihaqi, "Hingga September 2020, Ada 176 Pasangan Di Semarang Ajukan Dispensasi Kawin," JatengToday.Com, last modified 2020, accessed December 18, 2020, https://jatengtoday.com/hinggaseptember-2020-ada-176-pasangan-di-semarangajukan-dispensasi-kawin-63283.

${ }^{16}$ Bagya Agung Prabowo, "Pertimbangan Hakim dalam Penetapan Dispensasi Perkawinan Dini Akibat Hamil di Luar Nikah pada Pengadilan Agama Bantul," Jurnal Hukum IUS QUIA IUSTUM 20, no. 2 (2013): 306, https://journal.uii.ac.id/IUSTUM/article/ view/4522.
}

very urgent reasons accompanied by

sufficient supporting evidence “.

Regarding the implementation of giving dispensation to marriage, basically from within the judicial institution itself, there are several instruments that can help judges to produce decisions with a child perspective, such as Supreme Court Regulation (Perma) No.5 of 2019 concerning Guidelines for Adjudicating Applications for Marriage Dispensation (Perma No. 5 / 2019) and a more applicable form of a Handbook of Guidelines for Adjudicating Applications for Marriage Dispensation on 27 November 2020, where in general, these two instruments have been built on the same concerns as Law No.19 / 2019, namely preventing abuse of marriage dispensation in a manner inappropriate so that it does not affect the prevention of child marriage.

Then in practice, judges are expected to consider dispensation of marriage based on legal facts at trial such as evidence and also information from parents, the two prospective brides, witnesses who are present and from various points of view including juridical, sociological, psychological, and health considerations. which if described, among others: ${ }^{17}$

a. Children who are being applied for dispensation of marriage, for men already have jobs and income sufficient to meet household needs and for women must be accustomed to doing household chores;

b. The family of the man and woman have

\footnotetext{
${ }^{17}$ Rio Satria, "Dispensasi Kawin Di Pengadilan Agama Pasca Revisi Undang-Undang Perkawinan," Mahkamah Agung Republik Indonesia: Direktorat Jenderal Badan Peradilan Agama, last modified 2019, accessed November 24, 2020, https://badilag. mahkamahagung.go.id/artikel/publikasi/artikel/ dispensasi-kawin-di-pengadilan-agama-pasca-revisiundang-undang-perkawinan-oleh-rio-satria-16-10.
} 
agreed if the marriage is carried out;

c. The relationship between the prospective bride and groom is very close, if thenot immediately carried out marriage is, it is feared that they will take action that can destroy the good social life order;

d. The bride and groom have no obstacle to marriage.

In the case of the request for dispensation of marriage, what is often put forward is that the relationship between the prospective bride and groom is already so close that it is possible to postpone the marriage or even both have engaged in conjugal relations outside of marriage. ${ }^{18}$

However, if we connect the spirit of preventing child marriage and protecting children's rights with the law enforcement space, a less harmonious relationship can be found. Such as the case that occurred in South Sulawesi in 2018 where a marriage dispensation was granted by the court on the grounds that the male candidate wanted to marry because he was afraid to sleep alone. ${ }^{19}$ In addition, there are other decisions based on forced marriage because they are caught alone with a man who is not his family even though he is not having sexual relations or is pregnant. ${ }^{20}$ Even the dispensation of marriage which is sufficiently evident turns out to have a nega-

\footnotetext{
${ }^{18}$ Ibid., 1

${ }^{19}$ Anom Prihantoro, "KPAI: Dispensasi Usia Perkawinan Masih Disalahgunakan," AntaraKaltara, last modified 2019, accessed November 24, 2020, https:// kaltara.antaranews.com/nasional/berita/808600/ kpai-dispensas i-usia-perkawinan-masihdisalahgunakan?utm_source=antaranews\&utm medium=nasional\&utm_campaign=antaranews.

20 "Dampak Sosial Pandemi Corona, Pernikahan Gadis di Bawah Umur di Asia Meningkat," DW.com, accessed November 24, 2020, https:/www.dw.com/ $\mathrm{id} /$ pandemi-corona-memaksa-gadis-di-asia-menikahdi-bawah-umur/a-54780124.
}

tive impact, such as loss of opportunities to continue education, loss of freedom to develop like other children, becoming victims of domestic violence, and even having an impact on reproductive health. ${ }^{21}$

The phenomenon of disharmony between objectives and law enforcement has actually been limited through the explanation of Article 7 paragraph (2) of Law No.16 / 2019, which provides an explanation for the sentence "very urgent", which is: "What is meant by 'very urgent reason' is that there is no situation. another option and it is very compulsion to have a marriage done. ". Even though it only defines the phrase without providing clear indicators regarding the granting of dispensation to marriage, this explanation seems to have shown that in deciding applications for dispensation of marriage, judges should be able to see the reasons or background of the petition thoroughly (holistically) and in depth, not easily looking at the application. request for dispensation of marriage as a mere formal-procedural requirement. So that in relation to these arguments, in the next discussion, this paper will try to examine more deeply the construction of the judge's decision in viewing the application for dispensation of marriage.

\section{Positivist Legal Reasoning and Its Impact on Child Marriage Prevention Malfunc- tions}

When discussing the construction of a judge's decision and the process of identifying various aspects that affect the legal organ in making a decision, legal reasoning will be the main concept offered in a series of ongoing discourses. . The vital position of legal reasoning cannot be separated from its func-

\footnotetext{
21 "Putusan Mahkamah Konstitusi."
} 
tion of being able to provide the ability to solve a legal problem (case) by using special characters that come from the reflection of variables in the meta-juridical space of legal philosophy. ${ }^{22}$

Legal reasoning which is constructed by building a number of relationships with philosophical elements of law offers a number of frameworks for analyzing juridical phenomena, one of which is legal positivism. In general, positivists focus on legal norms that lie in rules that are passed by the competent authorities, so that positivists really value the existence of written rules and their role in dealing with various legal issues. ${ }^{23}$

One description of the concept of legal positivism was expressed by Hart who explained that: ${ }^{24}$

'The expression 'positivism' is used in contemporary Anglo-American literature to designate one or more of the following contentions: (1) that laws are commands of human being; (2) that there is no necessary connection between law and morals, or law as it is and law as it ought to be; (3) that the analysis or study of meanings of legal concepts is an important study to be distinguished from (though is no way hostile to) historical inquiries, sociological inquiries, and critical appraisal of law in terms of morals, social aims, function, etc; (4) that a legal system is a 'closed logical system' in which correct decisions can be

\footnotetext{
${ }^{22}$ Shidarta, Hukum Penalaran dan Penalaran Hukum: Akar Filosofis. (Yogyakarta: Genta Publishing, 2013), 429.

${ }^{23}$ Muhammad Erwin, Filsafat Hukum: Refleksi Kritis terhadap Hukum dan Hukum Indonesia (Dalam Dimensi Ide dan Aplikasi) (Jakarta: PT. RajaGrafindo Persada, 2016), 234-235.

${ }^{24}$ HLA Hart, The Concept of Law. (Oxford: Oxford University Press, 1961), 253.
}

deduced from predetermined legal rules by logical means alone; (5) that moreal judgments cannot be established, a statements of fact can, by rational arguments, evidence or proof ('non cognitivism in ethics'). “

Although this statement shows the existence of a gap between law and morals, other opinions state that in essence a positive law cannot be separated from the aspects of morality because the law is not related to matters of legitimacy alone. ${ }^{25}$ This is also in line with Stoljar's thought which assumes that the process of reasoning in written laws and practice (positivism) will always have a connection or interrelation with moral elements (naturalism), so that it is impossible to negate both. ${ }^{26}$ Apart from these differences in views, it cannot be denied that the main features of traditional to contemporary positivism are still not much different, that is the placement of legitimate written law as the "foundation stone" of the paradigm in law.

Related to the main problem in this paper, it is the mechanism for granting dispensation to marriage by District Court judges and Religious Court judges, the nuances of narrow positivist reasoning are still very clear in the construction of judges' considerations in deciding the dispensation request. However, this paper does not attempt to identify legal positivism as a bad, unusable and must be avoided law, but seeks to show that there is an abuse of the reasoning process that has an impact on legal malfunctions and offers a legal reasoning process capable of remembering, building

\footnotetext{
${ }^{25}$ Erwin, Filsafat Hukum: Refleksi Kritis terhadap Hukum dan Hukum Indonesia (Dalam Dimensi Ide dan Aplikasi), 236.

${ }^{26}$ Samuel Stoljar, Moral and Legal Reasoning. (London \& Basingstoke: The Macmillan Press LTD, London \& Basingstoke, 1980), 157-159.
} 
and rediscovering. The initial goal of establishing Law No. 16/2019 is the protection of children's rights in Indonesia.

Before looking deeper into the interrelation between legal positivism and these regulations, it is necessary to first understand the frame of mind that positivists use in building their legal arguments. Sidharta describes the configuration of legal positivism thinking to be in the form of atop-down one-wayor deductive, so that the pattern of reasoning starts from understanding normative premises and then using it in a case or legal fact. ${ }^{27}$

Demonstration 1.

Legal Positivism Reasoning ${ }^{28}$



Pattern This reasoning pattern can already be described when entering the space of this school of thought which places textual laws as the epicenter of its frame of mind and the consequences of losing moral position in the legal reasoning system make legal certainty as the main (axiological) value and one the only thing that this school contains, with the core value of legal certainty is predictability or an ability to perceive law as "an individual ought to behave in a certain way. ${ }^{29}$ This has led to the emergence of a number of diagno-

\footnotetext{
${ }^{27}$ Shidarta, Hukum Penalaran dan Penalaran Hukum: Akar Filosofis , 200-202.

${ }^{28}$ Ibid, 201.

${ }^{29}$ Ibid, 200.
}

ses to legal positivism as a flow that strengthens the concept of legism, that is a teaching which states that law does not exist or cannot be found when looking outside of legislation, so that law becomes the only source of law, and law and statute are two identical components. ${ }^{30}$ In western philosophy in general, radical positivistic legal reasoning against the text of this law can also be identified as an understanding of legalism, a concept that places moral relations regarding rights and obligations to be determined or dependent on existing regulations. ${ }^{31}$ West argues that this approach can be used to analyze legal questions that have the character of abstract logical reasoning that focuses on applicable legal texts, such as constitutions, statutes, or case law, rather than on social, economic, or political contexts. ${ }^{32}$

Apart from the allegations of the strong nuances of legism, dialectical developments have resulted in various criticisms of the legal positivism framework itself. As stated by Rahardjo, the domination of positivism in the intellectual space of law has given birth to a formal legal state that tends to leave substantial truths behind, and in the Indonesian context of an Indonesian state, a formal law state will not be able to bring happiness to the people. ${ }^{33}$ This argument does not accuse posi-

\footnotetext{
${ }^{30}$ Algra and Van Duyvendijk, Mula Hukum (terjemahan Rechtsaanvang oleh Simorangkir), Cetakan I. (Bandung: Bina Cipta, 1983), 137.

${ }^{31}$ Judith N. Shklar, Legalism: Law, Morals, and Political Trials. (Massacushetts, Harvard University Press, 1986), 1.

${ }^{32}$ Robin West, "Reconsidering Legalism," Minnesota Law Review 88, (2003): 119-121, https://scholarship. law.georgetown.edu/cgi/viewcontent.cgi?article $=127$ $4 \&$ context $=$ facpub.

${ }^{33}$ Satjipto Rahardjo, Negara Hukum yang Membahagiakan Rakyatnya. (Yogyakarta: Genta Press, 2008), 20-26.
} 
tivism of being the culprit, but shows the poor quality of law if it is only dominated by one thought and also identifies the existence of a vital element, that is substantial truth whose role is blurred due to the hegemony of legalism which is mechanistic and reductionist but is prioritized by law enforcers.

Law enforcers in this matter, The judges, occupy a vital position in discovering this substantial truth, and are said to be the last bastion in an effort to realize justice that makes the people happy. ${ }^{34}$ As in the dispensation of marriage decisions, in order to create a happy law, the judge must be able to see beyond mere formal-textual truth, by accommodating the main values and substances contained in Law No. 16/2019 about the protection of children's rights from underage marriage. ${ }^{35}$

The spirit of protecting children's rights is manifested in a number of clauses in the regulation, such as increasing the minimum age of marriage to 19 years (Article 7 paragraph 1) and tightening the provision of dispensation to marriage for underage couples (Article 7 paragraph 2). In addition, these clauses also depart from a number of analyzes which state that child marriage has an impact that not only injures human rights, but also has the potential to cause other harm to children such as exploitation, domestic violence to health problems both physically and psychologically. ${ }^{36}$ Thus, the judge must understand that by granting a request for dispensation of marriage, it means that the law has allowed child

\footnotetext{
${ }^{34}$ FX. Adji Samekto, Mendekonstruksi Adagium La Bouche De La Loi dalam Sistem Hukum Indonesia, dalam Mahrus Ali, Dimensi Filosofis: Ilmu Hukum \& Politik Hukum Pidana (70 Tahun Artidjo Alkostar Mengabdi Kepada Bangsa \& Negara). (Depok: Rajawali Press, 2013), 79-80.

35 "Pembinaan Hukum Nasional," 1-82.

${ }^{36}$ Ibid, 14-16.
}

marriage to occur which is of course followed by threats to the child as mentioned above.

However, if you look at the high number of applications for dispensation of marriage that are granted by the court, it can be said that law enforcers, especially judges, do not understand the consequences of the existence of the marriage dispensation mechanism and only understand it as a "textual truth". ${ }^{37}$

This situation itself is a consequence of the positivistic-legalistic reasoning used by the judge by placing the dispensation of marriage as a truth in the law which must be accommodated by the law. Dispensation of marriage which is an optional component has shifted to become part of the "mandatory" component in the series of underage marriage processes as a consequence of a positivistic understanding of its textual existence in the law which judges deem to be realized without considering the phrase "very urgent" contained in Article 7 paragraph 2. Thus, the condition that the judge has no choice but to grant the marriage dispensation request can lead to malfunction of Law No. 16/2019 in realizing the protection of children's rights from underage marriage.

\section{The Urgency of Judge Progressivism in the Requesting Mechanism for Marriage Dis- pensation}

As expressed by Taverne, if a good rule is

\footnotetext{
${ }^{37}$ A. Sukris Sarmadi, "Membebaskan Positivisme Hukum Ke Ranah Hukum Progresif (Studi Pembacaan Teks Hukum Bagi Penegak Hukum)," Jurnal Dinamika Hukum 12, no. 2 (2012): 331, http://dinamikahukum.fh.unsoed.ac.id/index.php/ $\mathrm{JDH} /$ article/view/58/. In this case "textual truth" is defined as a phenomenon where the focus of truth is the text of regulations known as legislation, laws which in their true form are not limited are reduced to a certain extent with deterministic and mechanistic characteristics.
} 
in the hands of a bad law enforcer then it will result in bad law, and conversely, bad rules if it is in the hands of a good law enforcer will produce a good law. . ${ }^{38}$ The adage provides a profound picture of the vital position of the judge in realizing an ideal legal utopia even though it must be limited by unsupportive juridical equipment.

Apart from the formal analysis regarding the quality of the composition of Law no. $16 / 2019$, judges are required to be able to find, understand and build a fair law from these regulations, by freeing themselves from the rigidity of a positivist legal reasoning process. So that law enforcers must be directed outward or freed from positivist rigidity towards progressive legal dynamism in order to fulfill the demand to "free judges" from textual reasoning on the marriage dispensation mechanism in Law no. 16/2019. ${ }^{39}$

This argument is based on a number of reasons, among others, first, the pattern of legal positivism reasoning against the textual formulation of laws can result in a rigid understanding of the law which results in the loss of substance or the main meaning of the regulation. Second, losing the meaning and purpose of the formation of Law no. 16/2019 could have an impact on the loss of the main function of this regulation, which is the protection of the human rights of children from

\footnotetext{
${ }^{38}$ Bernardus Maria Taverne, dalam Syamsudin, Konstruksi Baru Budaya Hukum Hakim: Berbasis Hukum Progresif (Jakarta: Kencana Prenada Media Group, 2012), 5.

${ }^{39}$ Sarmadi, "Membebaskan Positivisme Hukum Ke Ranah Hukum Progresif (Studi Pembacaan Teks Hukum Bagi Penegak Hukum).” 332, The term "release judge" is defined as an effort to remove judges from law enforcement with a positivistic character. Positivism is considered as a cause of justice defined only in legislations, and law is nothing more than a formalistic mathematical sketch.
}

underage marriage. Third, the positivistic-legalistic logic which assesses the appropriateness of giving dispensation to marriage only on the basis of compliance with the existing procedures will create a "legal logic trap". ${ }^{40}$ Where the clause in the law is understood as nothing more than a formality in the administration of justice due to regulations which should serve as a reminder of the dangers of underage marriage being narrowly logged only as a result of a series of "legal" activities and will become a law enforcement tool that can be used for legal purposes. excess interest. ${ }^{41}$ Fourth, law enforcers who fail to understand the purpose of the law and its benefits for society will create a "court dictatorship" which results in the formation of a law enforcement culture that is unfriendly and sensitive to children's rights. ${ }^{42}$ Fifth, the main principle in progressive law, namely "law for humans, not humans for law", offers a number of thinking tools capable of encouraging judges to be willing to offer non-conventional or solutions out of the box by continuing to encourage judges to test the limits of the legal text's ability., which in this case is useful in

\footnotetext{
${ }^{40}$ Satjipto Rahardjo, Membedah Hukum Progresif, (Jakarta: Kompas, 2008), 124. Judges are expected to be able to read the rule of law by diving into the spirit, principles and objectives of law in order to avoid the dangerous trap of legal logic, a part of legal logic that is counterproductive because it is based on individual or group.

${ }^{41}$ Tundjung Herning Sitabuana, Berhukum di Indonesia (Jakarta: Konstitusi Press, 2017), 4. The law here means that it is related to the process of making good and correct laws, not against the constitution and other existing regulations.
}

${ }^{42}$ Satjipto Rahardjo, Penegakan Hukum Progresif (Jakarta: Kompas, 2010), 184-185. Judicial Dictatorship is a term used by Rahardjo in describing the phenomenon of the court's isolation from seeking to know the needs of society by law and only willing to follow formal legal needs. 
creating a judicial climate that is suitable for the development of the ability of judges' interpretation and the effectiveness of preventing underage marriages. ${ }^{43}$

The urgency of changing the judge's reasoning in seeing the existence of Law no. $16 / 2019$ itself must be understood not only as a component in legal discovery (rechtsvinding), but more broadly as an idea or ideas for reform of a progressive court that is able to interact with the dispensation mechanism for marriage and children that prioritizes the conscience and human rights of children. This can be realized by legal progressivism because of its function which is not only limited as a process of reasoning, but also as an intellectual movement of law. ${ }^{44}$

The integrated legal science learning can be found in the written pieces of the ideas of the initiator, Satjipto Rahardjo, either collected in a book or descriptions in journals, newspapers or seminars, which generally contain a number of conceptual outlines of progressive legal ideas, which are ${ }^{45}$

a. Progressive law exists to serve man, not

\footnotetext{
${ }^{43}$ Satjipto Rahardjo, "Pidato Sambutan Seminar “Prospek Hukum Progresif di Indonesia”(Semarang 2009), dalam Shidarta, "Posisi Pemikiran Hukum Progresif Dalam Konfigurasi Aliran-Aliran Filsafat Hukum: Sebuah Diagnosis Awal" (Jakarta, 2010)., dalam Myma Safitri, Awaludin Marwan and Yance Arizona, eds., Satjipto Rahardjo dan Hukum Progresif: Urgensi dan Kritik, (Jakarta: Epistema Institute, 2011), 55-56.

${ }^{44}$ Ibid, Hal.53-54. There are a number of views that see progressive law not only as a tool for legal discovery (rechtsvinding), which means that as long as someone interprets and applies the law by not following the sound of the legal text because of an injustice, then he will already think following the flow of progressive legal thought.

${ }^{45}$ Shidarta, Posisi Pemikiran Hukum Progresif dalam Konfigurasi Aliran-Aliran Filsafat Hukum: Sebuah Diagnosis Awal, 55-58.
}

the other way around, man to law. This principle provides an illustration that the law does not exist for itself, but for a greater thing.

b. In its enforcement, progressive law must be pro-people and pro-justice. The law should come down to the bottom, seek and find justice from the spaces of society below (turba).

c. Progressive laws are designed to give man welfare and happiness, law is required to have an objective that is further than the goal of liberal philosophy (legal certainty).

d. Progressive law has a characteristic that is always in the form of a process (law as a process). Every decision produced by the judicial institution will be terminal in nature in an effort to achieve a better and ideal next decision.

e. Progressive law builds a rule of law with a conscience. The rule of law created by progressive law prioritizes a culture of enforcement (cultural primacy). This legal culture must be rich in values that make the people happy and not be concerned with technical-mechanical structures in law enforcement.

f. Progressive law breaks through and frees the law fromattitudes status quo and submissive, which makes the law lead to absolute / absolute truths.

g. The quality and progress of law enforcement lies in the law enforcers themselves. Even good laws will become bad laws if they are in the hands of law enforcers with bad quality of conscience and integrity . On the other hand, if law enforcers are of good quality, then bad laws will be good and produce justice.

h. Progressive law encourages public engagement. Progressive law emphasizes the 
mobilization of the autonomous power of society.

i. Progressive law is carried out by promoting spiritual intelligence. In seeking to find the truth and deeper legal meaning, it is fitting that these efforts are not limited by textual or contextual rigidity.

The concepts contained in the big idea of progressive law encourage changes in law enforcement of the dispensation of marriage from a child perspective and narrow the space for child marriage to occur on the basis of "haphazard" considerations. Based on this, the contribution of the idea of legal progressivism above can be applied in a number of juridical aspects of judges in granting dispensation of marriage, namely, First, legal progressivism provides new glasses for judges in understanding the indicators of granting marriage dispensation more broadly and its consequences. Second, the creation of a legal culture that is friendly to children's human rights through the release of judges from the technical-mechanical "comfort zone", so that the main targets to be achieved by Law no. $16 / 2019$ can be achieved through this progressive-responsive judicial institution. Third, the expected outcome of the fundamental shift in progressive law enforcement on the regulation is the creation of effective and "sustainable" protection of children's rights through the provision of dispensation for marriage based on the greatest possible justice for children. ${ }^{46}$

\footnotetext{
${ }^{46}$ Satjipto Rahardjo, Hukum Progresif: Kesinambungan, Merobohkan dan Membangun, Ufran, eds., Hukum Progresif: Sebuah Sintesa Hukum Indonesia, (Yogyakarta: Genta Publishing, 2009), 57-60. Progressive law offers a sustainable legal feature that is able to continue to build, grow and develop towards newness in carrying out its role as a servant
}

\section{CONCLUSION}

Adjusting the new age limit for women and men, it is 19 years, encourages the birth of a marriage dispensation mechanism through Law no. 16/2019 which was built with the spirit of anti-discrimination and protection of children's rights from underage marriage. However, the ideal legal utopia that the regulation intends to establish is still seen as a mere textual guide by law enforcers, increasing the age limit as a condition of marriage only creates a legal consequence, which is the dispensation of marriage as an additional procedural step for couples wishing to have child marriage. This situation may continue if judges continue to use positivist reasoning patterns in understanding regulations and processing applications for dispensation of marriage, so that at this stage a shift in reasoning patterns towards progressive law is needed which is able to guide judges in carrying out law enforcement that find and build ideal legal ideals. which Law no. 16/2019 on the protection of children's rights which is based on maximum justice for children.

\section{Suggestions}

It is necessary to have a deep understanding of the legal objectives to be achieved by Law no. 16/2019 by shifting legal positivism reasoning with progressive legal reasoning that is able to create protection of children's rights from the adverse effects of child marriage. Then, specifically the meaning of the sentence "The urgent reasons " contained in the Explanation of Article 7 paragraph (2) of Law no. $16 / 2019$ must be seen as an inhibiting feature of the child marriage phenomenon in order to create laws that guarantee children's human rights, so that dispensation of marriage must

to humanity, so it is said that law can only survive to regulate if the law is dynamic and progressive 
be seen as the last option, not part of the procedural stage of underage marriage.

\section{BIBLIOGRAPHY}

\section{Books}

Algra, and Van Duyvendijk. Mula Hukum (terjemahan Rechtsaanvang oleh Simorangkir). Cetakan I. Bandung: Bina Cipta, 1983.

Coontz, Stephanie. Marriage, a History: From Obedience to Intimacy or How Love Conquered Marriage. New York: Viking Books, 2006.

Erwin, Muhammad. Filsafat Hukum: Refleksi Kritis terhadap Hukum dan Hukum Indonesia (Dalam Dimensi Ide dan Aplikasi). Jakarta: PT. RajaGrafindo Persada, 2016.

Hart, HLA The Concept of Law. Oxford: Oxford University Press, 1961.

Rahardjo, Satjipto. Membedah Hukum Progresif. Jakarta: Kompas, 2008.

Rahardjo, Satjipto. Negara Hukum yang Membahagiakan Rakyatnya. Yogyakarta: Genta Press, 2008.

Rahardjo, Satjipto. Penegakan Hukum Progresif. Jakarta: Kompas, 2010.

Rahardjo, Satjipto. "Pidato Sambutan Seminar "Prospek Hukum Progresif Di Indonesia." Semarang, 2009.

Safitri, Myma, Awaludin Marwan and Yance Arizona, eds. Satjipto Rahardjo dan Hukum Progresif: Urgensi dan Kritik. Jakarta: Epistema Institute. 2011.

Samekto, FX. Adji. Mendekonstruksi Adagium La Bouche De La Loi dalam Sistem Hukum Indonesia, dalam Mahrus Ali, Dimensi Filosofis: Ilmu Hukum \& Politik Hukum Pidana (70 Tahun Artidjo Alkostar Mengabdi Kepada Bangsa \& Negara). Depok: Rajawali Press, 2013.

Shidarta. Hukum Penalaran dan Penalaran
Hukum: Akar Filosofis. Yogyakarta: Genta Publishing, 2013.

Shidarta. "Posisi Pemikiran Hukum Progresif Dalam Konfigurasi Aliran-Aliran Filsafat Hukum: Sebuah Diagnosis Awal.” Jakarta, 2010.

Sitabuana, Tundjung Herning. Berhukum di Indonesia. Jakarta: Konstitusi Press, 2017. Shklar, Judith N. Legalism: Law, Morals, and Political Trials. Massacushetts: Harvard University Press, 1986.

Stoljar, Samuel. Moral and Legal Reasoning. London \& Basingstoke: The Macmillan Press LTD, London \& Basingstoke, 1980. Syamsudin. Konstruksi Baru Budaya Hukum Hakim: Berbasis Hukum Progresif. Jakarta: Kencana Prenada Media Group, 2012.

Ufran, eds. Hukum Progresif: Sebuah Sintesa Hukum Indonesia, Yogyakarta: Genta Publishing, 2009.

Wignjosoebroto, Soetandyo. Hukum: Paradigma, Metode dan Dinamika Masalahnya. Jakarta: Lembaga Studi dan Advokasi Masyarakat (ELSAM) dan Perkumpulan untuk Pembaruan Hukum Berbasis Masyarakat dan Ekologi (HUMA), 2002.

\section{Journal}

Prabowo, Bagya Agung. "Pertimbangan Hakim dalam Penetapan Dispensasi Perkawinan Dini Akibat Hamil di Luar Nikah pada Pengadilan Agama Bantul." Jurnal Hukum IUS QUIA IUSTUM 20, no. 2 (2013): 306. https://journal.uii.ac.id/IUSTUM/article/view/4522.

Baiquni, M. "Revolusi Industri, Ledakan Penduduk dan Masalah Lingkungan.” Jurnal Sains dan Teknologi Lingkungan 1, no.1 (2009): 44-46. https://journal.uii.ac.id/ JSTL/article/view/3568/3158.

Ilma, Mughniatul. "Regulasi Dispensasi 
Dalam Penguatan Aturan Batas Usia Kawin Bagi Anak Pasca Lahirnya UU No. 16 Tahun 2019." Al-Manhaj: Jurnal Hukum dan Pranata Sosial Islam 2, no.2 (2020): 147. https://ejournal.insuriponorogo.ac.id/index.php/almanhaj/article/view/478.

Sarmadi, A. Sukris. "Membebaskan Positivisme Hukum Ke Ranah Hukum Progresif (Studi Pembacaan Teks Hukum Bagi Penegak Hukum)." Jurnal Dinamika Hukum 12, no.2 (2012): 331. http://dinamikahukum.fh.unsoed.ac.id/index.php/JDH/article/view/58/24.

Hidayatullah, Syeh Sarip and Nurul Huda. "Praktek Hukum Acara Dispensasi Kawin." Asas: The Scientific Journal of Politics, Law, Syari'ah Economic Law and Islamic Culture, 12, no.1 (2020): 167. http:/ejournal.radenintan.ac.id/index.php/ asas/article/view/7133

West, Robin. "Reconsidering Legalism." Minnesota Law Review 88, (2003): 119121. https://scholarship.law.georgetown. edu/cgi/viewcontent.cgi? article $=1274 \&$ co ntext=facpub.

\section{Internet}

"Angka Pernikahan Anak di Jateng Naik Jadi 8.338 Kasus." Kompas. last modified 2020. Accessed December 18, 2020. https://regional.kompas.com/ $\mathrm{read} / 2020 / 11 / 21 / 17464361 /$ angkapernikahan-anak-di-jateng-naik-jadi8338-kasus?page=all.

“Child Marriage." United Nation Children's Fund, last modified 2020. Accessed November 20, 2020. https://data.unicef.org/ topic/child-protection/child-marriage/.

"Pencegahan Perkawinan Anak: Percepatan yang Tidak Bisa Ditunda." Puskapa-Center on Child Protection and Wellbeing at
Universitas Indonesia. last modified 2020. Accessed November 24, 2020. https:// www.unicef.org/indonesia/media/2851/ file/Child-Marriage-Report-2020.pdf.

"Dampak Sosial Pandemi Corona, Pernikahan Gadis di Bawah Umur di Asia Meningkat." DW.com. Accessed November 24, 2020. https://www.dw.com/id/pandemicorona-memaksa-gadis-di-asia-menikahdi-bawah-umur/a-54780124.

Satria, Rio. "Dispensasi Kawin Di Pengadilan Agama Pasca Revisi Undang-Undang Perkawinan." Mahkamah Agung Republik Indonesia: Direktorat Jenderal Badan Peradilan Agama. Last modified 2019. Accessed November 24, 2020. https:// badilag.mahkamahagung.go.id/artikel/ publikasi/artikel/dispensasi-kawin-dipengadilan-agama-pasca-revisi-undangundang-perkawinan-oleh-rio-satria-16-10.

Baihaqi. "Hingga September 2020, Ada 176 Pasangan Di Semarang Ajukan Dispensasi Kawin." JatengToday.Com. Last modified 2020. Accessed December 18, 2020. https://jatengtoday.com/hingga-september-2020-ada-176-pasangan-di-semarangajukan-dispensasi-kawin-63283.

WR, Andi Muhammad Ikhsan. "Hingga Oktober 2020, Permohonan Dispensasi Nikah Di Pengadilan Agama Maros Capai 203 Kasus." TribunMaros. Last modified 2020. Accessed November 24, 2020. https:// makassar.tribunnews.com/2020/11/04/ hingga-oktober-2020-permohonan-dispensasi-nikah-di-pengadilan-agama-maros-capai-203-kasus.

Prihantoro, Anom. "KPAI: Dispensasi Usia Perkawinan Masih Disalahgunakan." AntaraKaltara. Last modified 2019. Accessed November 24, 2020. https://kaltara.antaranews.com/nasion- 
al/berita/808600/kpai-dispensasi-usiaperkawinan-masih-disalahgunakan?utm s o u r c e $=$ a n t a ra n e w s \& u t m $\mathrm{m} \mathrm{e} \mathrm{d} \mathrm{i} \mathrm{u} \mathrm{m}=\mathrm{n}$ a s i o n a $1 \&$ u $\mathrm{tm}$ campaign $=$ antaranews.

"Permohonan Dispensasi kawin Anak di Loteng Meningkat 300 Persen." RadarLombok. last modified 2020. Accessed November, 24, 2020. https://radarlombok. co.id/permohonan-dispensasi-perkawinan-meningkat-300-persen.html.

"Proyeksi Penduduk Indonesia (Indonesia Population Projection) 2010-2035." Badan Perencanaan Pembangunan Nasional Badan Pusat Statistik, Last modified 2013. Accessed November 20, 2020. https://www.bappenas.go.id/ files/5413/9148/4109/Proyeksi_Penduduk_Indonesia_2010-2035.pdf. 